\title{
RIJOQ: VOCAL MUSIC OF DAYAK BENUAQ FROM KUTAI, EAST KALIMANTAN
}

\author{
Ester* \\ Agastya Rama Listya** \\ *Satya Wacana Christian University of Salatiga, Indonesia \\ E-mail: ester_syg@yahoo.co.id \\ **Satya Wacana Christian University of Salatiga, Indonesia \\ E-mail: agastya123@yahoo.com
}

Received: June 2013. Accepted: Februari 2014. Published: Maret 2014

\begin{abstract}
Rijoq, a Dayak Benuaq vocal music, has been passed down from generation to generation through oral tradition for hundreds of years. When and how it was founded, developed and preserved in the Dayak community remains questionable. But according to some research done by scholars, Rijoq has its origin from Dayak Bawo, a tribe living in the borderlines between Central, South, and East Kalimantan. Rijoq is normally performed during festivities, such as: initiation, reconciliation, menugal (rice planting) and potong kerbau (buffalo slaughtering). Rijoq's texts have very deep messages which are considered still relevant to today's life context. On the one hand, it speaks about the horizontal relationship - human beings and their fellows, and human beings and its nature -; and on the other hand, the vertical relationship - human beings with their Creator. The primary concern of doing this research is to preserve Rijoq as written and recorded documents. So far, this research has been successful in notating and recording five kinds of Rijoq, that is Peket Muat Bolupm (working together to build lives), Rijoq Patuk Ajer (advice), Rijoq Natal Tautn Bayuq (Christmas and New Year), Rijoq Isiq Asekng Sookng Bawe (the expression of a man's feeling who is falling in love with a woman), and Rijoq Lati Tana Orekng Tepa (forests and lands are disappearing and gone). But this paper is not intended to discuss these five kinds of Rijoq. Isiq Asekng Sookng Bawe is chosen as it is the oldest and the most difficult Rijoq among the rest.
\end{abstract}

(C) 2014 Sendratasik FBS UNNES

Keywords: Rijoq; Dayak Benuaq; Bekeleeu

\section{INTRODUCTION}

In general all Dayak tribes were the descendants of Chinese immigrants that emigrated from Yunnan in South China (Commans, 1987, p. 3-4). No wonder that some names such as Apui, Bi Lung and Kun Dung Ga which are very common in South China also used as Dayak's names in East Kalimantan (Soemargono et. al, 1992, p. 12). Some scholars believe that Dayak Benuaq was a mixture between Malay, Wedoide and Mongoloide, and characterized by some physical similarities. Ahmad Yunus concludes that Dayak Banuaq originated from the borderlines between Central Sulawesi and Serawak, Malaysia (Yunus, 1992, p. 31). The Ahmad Yunus' conclusion is supported by some similarities found in these two areas, particularly tools used for cultivating the field, battling, hunting the animals, burying the dead bodies, and worshiping the souls of their ancestors.

In their original place, Dayak Benuaq was formerly called "Luangan". Due to geographical situation and the pressure 
brought by an Iban tribe from the Northern area, Dayak Benuaq has been forced to move to East Kalimantan.In their new home place, they called themselves "Benuaq", which possibly came from the word "Benuaqkn", a name of their new place.

According to their belief, Benuaq is associated with Ningkah or Nyingkah Oloo, a figure of demigod (Dyson, 2008, p. 16-17). The descendants of Nyingkah Oloo spread from the riverside (close to Samarinda, South Kalimantan) to the upper course of Mahakam, a place known as $\mathrm{Gu}$ nung Lipan (Centipede Mountain). On this mountain, Nyingkah Oloo built his home, a place where many poisonous centipedes were living (Dyson, 2008, p. 19-20).

Nyingkah Oloo was married to a Bugis woman, named Dayaang Beliaant. However the name of Tenggarong as the capital of Kutai palace did not come from the Bugis words "tangga arung" (king's ladder), but from "wakaai engkaruukng" (Benuaq words meaning wooden root that is frequently used for a fireplace when the people are working together to build their new city). Benuaq people call Tenggarong with "tengkaruukng".

\section{Rijoq}

Dayak Benuaq sing their songs in the social and the religious events. The texts of these songs are written in the high literary language that only can be understood by the language experts. Every singer who wants to master the texts and the songs used in the religious events should go through a ritual process.

According to Septianus B., Dayak Benuaq's songs are divided into two, that is sacred and secular. The sacred pieces are in the form of magic formula or sung story that only can be performed during the religious rites. Some kinds of secular pieces are: dodo (sung poetry or fairy tale), de$q u g$ (poetry or fairy tale similar to dodo but sung in the faster tempo), loak (songs used during the kampong thanksgiving ceremony), lengot (similar to loak but written in different rhythm and notation), and rijoq (a traditional poetry that is sung during spe- cial or wedding ceremonies).

\section{The History of Rijoq}

None of the Rijoq players know when Rijoq was born, but they all are convinced that Rijog has been passed down from generation to generation for hundreds of years. F. Setianus B., Rijoq is truly convinced that Rijoq was originated from Dayak Bawo living in the borderlines between Central, South, and East Kalimantan (now is known as North Barito district). North Barito once was known as a tribe with high cultures and so much influenced by Hin$\mathrm{du}$. This tribe is well known as the creator of noble literatures, such as metaphors, aphorism, fairy tales, and Rijoq.

According to the mythology, all joyful arts including Rijoq have its origin in bekeleu ceremony. This ceremony began with the victory of Tatau Mukng Batuqover the Aput Pererawetn village. After the battle, Tatau Mukng Batuq got a serious illness although beliatn ceremony had been offered. One day, Tatau Mujaaq Tuhaaq, Batuq's father, had a dream. In his dream, an old man with white hair telling him that Batuq's illness was a result of nayuq's and tiger's curse. The spirit of nayuq and the tiger got mad at Tatau Mukng Batuq for not holding pesengkeet nayuq eremony as a thanksgiving over the victory he had achieved. This old man, then suggested Batuq's father to hold a bekeleeu ceremony to expel the evil spirits that were sent by nayuq and the tiger (Madrah, 1997, p. 136).

Bekeleeu ceremony has marked the beginning of all joyful Dayak arts, including Rijoq. It has become a strong reason why performing Rijoq during the times of sorrow will result in buhotn (struck down by death) (Irwanto, 2010, p. 63).

Dayak Benuaq has adopted a lot of Dayak Bawo literatures, e.g. rijog and beliatn ceremony. It was possible because Dayak Benuaq did a lot of travels to other Dayak kampongs. Another reason is Dayak Benuaq lived side by side and intermixed with Dayak Bawo. 


\section{The Functions of Rijoq}

Rijoq is usually performed during joyful ceremonies. It is first an amusement for the performers itself, particularly during menugal (sowing the rice seed), buffalo slaughtering, or when the women preparing the logistic for menugal (Irwanto, 2010, p. 63), or when the women picked up doyo leaves for making ulap doyo (piece of cloth made of leave doyo fiber. The making process takes quite a long time because the fibres should be separated first from its leaves before drying and spun). Later, $R i$ $j o q$ is also sung during the initiation, such as: birth, marriage, expelling calamity (nalitn tautn) and peace ceremonies (nuaak mikaat lait). Nalitn tautn is ceremony aims to expel the disaster caused by incest, so that the farmers may harvest rice.

\section{The Lyrics and the Forms of Rijoq}

Rijoq is a speech literature-a kind of literature that has been passed down from generation to generation through oral tradition, for instance, a traditional poetrythat is sung without any music accompaniment. Therefore, a Rijoq singer is required to be able to show his/hermusical ability. In this present day, Rijog is no longer an unaccompanied song, but it has been furnished with musical instruments such as: sapeq, guitar, drum set, synthesizer, sulking (a wooden flute that's rarely found in the performances today). Its verse comprises of two couplets with each line ends with a rhyme. Its texts speak about the relationships between human beings and its Creator, human beings with their fellows, and human beings with its nature. At the beginning Rijoq was written in an archaic Benuaq language, but later to adjust to the situation, Rijoq's texts use modern language.

Rijoq is sung by one singer or two alternates. Rijoq has a unique ornament that usually placed on the syllables that are located at the beginning or in the middle, and never in the end of a song phrase. The main feature of Rijoq is the absence of refrain. It has a lyrical melody, tempo which is relatively constant throughout the song, and quite a complicated rhythmic pattern. The skill of the singers will determine the complexities of its Rijoq's rhythmic pattern. In the other word, the more skilful the singer, the more complicated the Rijoq's rhythmic pattern will be.

Rijoq Isiq Asekng Sookng Bawe (The expression of a man who is falling in love with a woman)

Rijoq Isiq Asekng Sookng Bawe has three motives (figures 1, 2, and 3) and all texts are set in the strophic form.

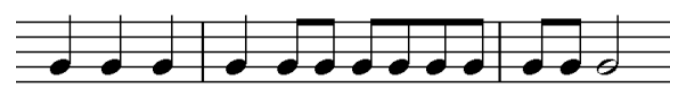

Figure 1. Rhythmic Motive 1 Rijoq Isiq Asekng Sookng Bawe

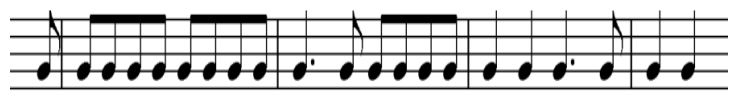

Figure 2. Rhythmic Motive 2 Rijoq Isiq Asekng Sookng Bawe

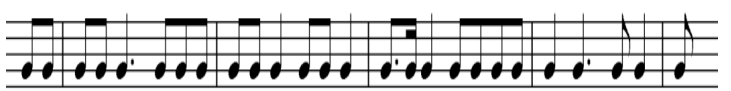

Figure 3. Rhythmic Motive 3 Rijoq Isiq Asekng Sookng Bawe

Rijoq Isiq Asekng Sookng Bawe is also decorated with some ornaments which in Western notation similar to acciaccatura, trill, and slide (figure 4). Isik Asekng Sook$n g$ Bawe is considered as an old Rijoq and demands high skills of its performers. This Rijoq is performed without any accompaniment so singer's creativity and musicality are required.

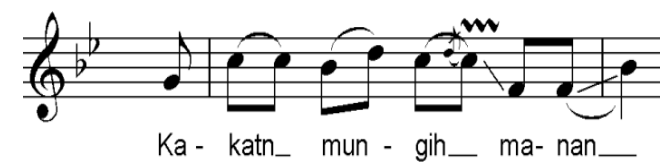

Figure 4. Rijoq Isiq Asekng Sookng Bawe's ornaments

Rijoq Isiq Asekng Sookng Bawe is a traditional poetry consisting of six stanzas. Each stanza has six lines with the rhyme orders as follow: $\mathrm{a}-\mathrm{a}-\mathrm{a}$ and $\mathrm{a}-\mathrm{b}-\mathrm{b}$. The 
sentence dodoi dinang ayoq sayang which does not have any meaning is added to complement the existing melody. Its texts talk about the love between a man and a woman. This Rijoq may be performed by male and female singers as a responsorial.

The message of this Rijoq: love relationship is a holy one and it is not merely about sexual relationship. Every Dayak person should understand the true meaning of love and should find his/her partner seriously.

\section{Empit incatn mungih ori}

Kakatn mungih manan langit akuq lilikng langit

Dodoi dinang ayo sayang langit akuq lilikng langit

Kami kemkepm mungih kami

Elokng mungih bungaq kami akuq

kemkepm lei kami

Dodoi dinang ayoq sayang kami

kemkepm lei kami

Empit incatn mungih ori

Oroq mungih manan langit kuq

lilikng lei langit

Dodoi dinang ayoq sayang langit akuq

lilikng langit

Kami kemkepm mungih kami

Ituq mungih bungaq kami akuq

kemkepm lei kami

Dodoi dinang ayoq sayang kami akuq

kemkepm kami

Empit incatn mungih lewekng

Epuq mungih manan langit akuq

lilikng langit

Dodoi dinang ayoq sayang langit akuq

lilikng lei langit

Asekng kemkepm mungih asekng

Elokng mungih bungaq kami asekng

akuq kemkepm lei asekng

Dodoi dinang ayoq sayang asekng

Empit incatn mungih lewekng

Oroq mungih manan langit akuq

lilikng lei langit

Dodoi dinang ayoq sayang langit akuq

lilikng langit

Asekng kemkepm mungih asekng

Elokng mungih bungaq kami asekng

akuq kemkepm lei asekng
Dodoi dinang ayoq sayang asekng

Ayo butuq mungih umaq

Amen mungin bungaq konaq akug

masengkonaq

Dodoi dinang ayoq sayang konaq akuq

Masengkonaq

Ruku bere mungih ruku

Ayoq mungih alukng ruku akuq bere

lei ruku

Dodoi dinang ayoq sayang akuq bere

lei ruku

Ayo botuq mungih suru

Aweq lekaq nyalaq akuq nentakng lei

nyalaq

Dodoi dinang ayoq sayang nyalaq

akuq nentakng lei nyalaq

Ruku bere mungih ruku

Uhatn mungih olukng ruku akuq bere

lei ruku

Dodoi dinang ayoq sayang ruku akuq

bere ruku

Meaning:

A sparrow perches on a house post I wish to wander around the sky

I wish to wander around the sky

Holding hands together

To find the flowers to hold on

To find a girl to marry

A sparrow perches on a house post

To walk far away circling around

the sky

To walk far away to all

destinations

Holding hands together

That is the flower to hold on

This is the girl that is ready

to marry

A sparrow perches on a rice

winnow

Have travelled circling around

the sky

Have travelled to all destinations

Sweetheart

To find the flower

Sweetheart

To find a girl, my heart desire

A sparrow perches on a rice

Winnow

To walk far away circling around

the sky

To walk far away to all 
destinations

Sweetheart

To find the flower,

Sweetheart

This is the girl, my heart desire

Sweet potatoes in the field

If the flower agrees

If the flower does not mind

to meet

Could we meet directly?

Let us make a promise to meet

Sweet potatoes in the field that has

been burned

There is nothing wrong

There is no need to feel shy and

guilty

to meet

We are about to meet

We will meet immediately

\section{CONCLUSION}

The deep moral message of Rijoq's texts is still considered relevant to today's context. Rijoq Isiq Asekng Sookng Bawe is just an obvious example of how a hundred-year text could bring a strong message to today's people who are ignoring the holiness of love. This research is just a beginning indeed. Many remain hidden and covered. Hopefully, this research will stimulate other researches which try to in- ventories and to preserve Rijoq as a completed written document.

\section{REFERENCES}

Commans, M. (1987). Manusia Dayak Dahulu, Sekarang, Masa Depan. Jakarta: PT Gramedia.

Dyson, P.L. (2008). Sejarah Sendawar 2. Surabaya: Airlangga University Press.

Irwanto. (2010). Kesenian Rijoq: Fungsi dan Keberadaannya. Thesis. Surakarta: Master's Degree at Postgraduate Program at Institut Seni Indonesia Surakarta.

Soemargono, K. et al. (1992). Profil Propinsi Republik Indonesia-Kalimantan Timur. Jakarta: Yayasan Bhakti Wawasan Nusantara.

Madrah, T.D. (1997). Tempuutn: Mitos Dayak Benuaq dan Tujung. Jakarta: Puspa Swara.

Yunus, A. (1992). Upacara Tradisional (Upacara Kematian) Daerah Kalimantan Timur. Jakarta: Depdikbud.

\section{Interviews:}

Interview with F. Setianus B. on June 25, 2009.

Interview with F. Setianus B. on August 8, 2011. 
Appendix

\author{
Rijoq Isiq Asekng Sookng Bawe
}
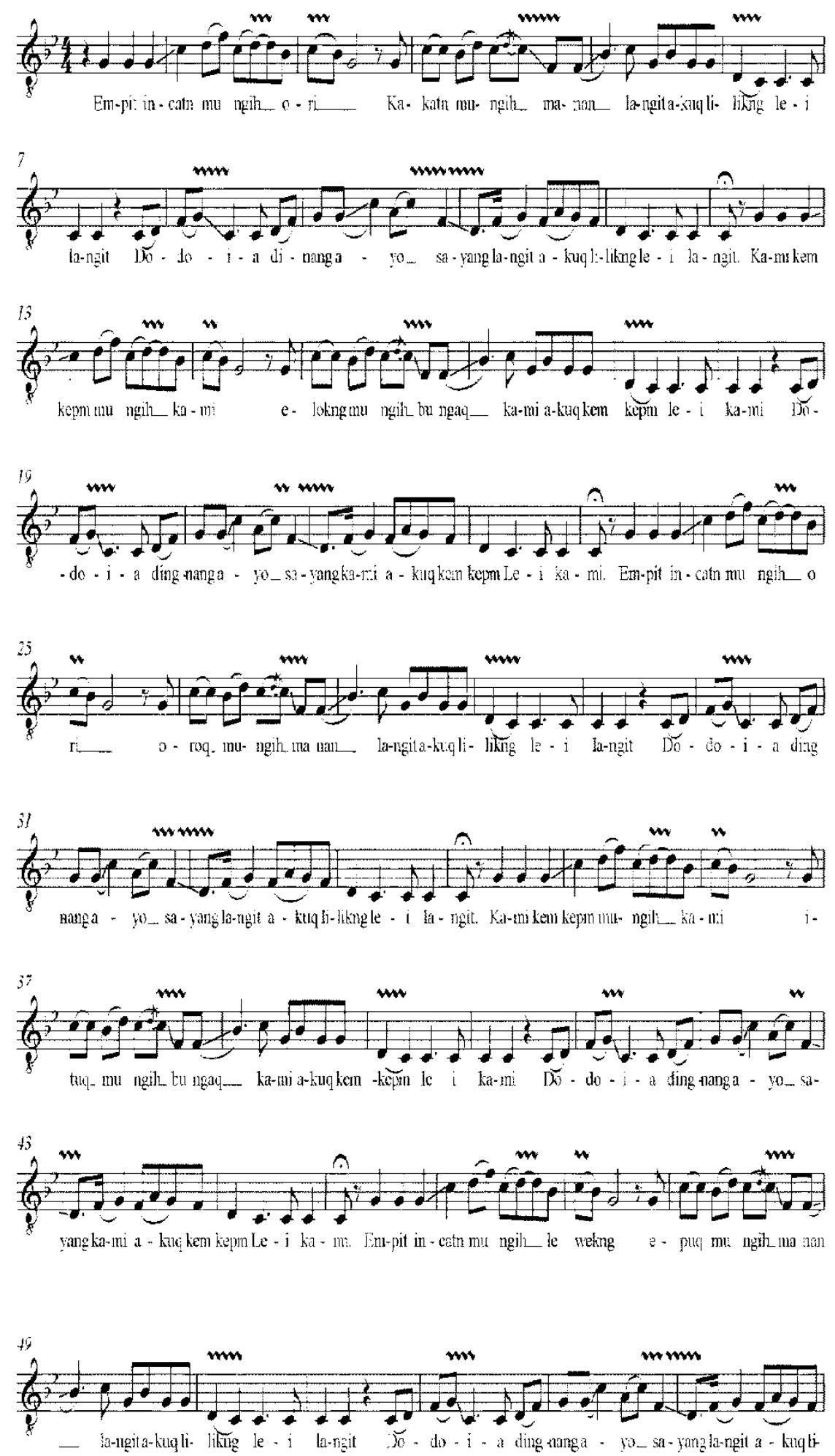


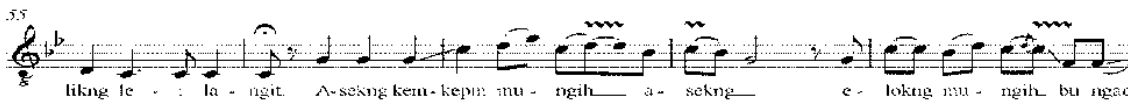

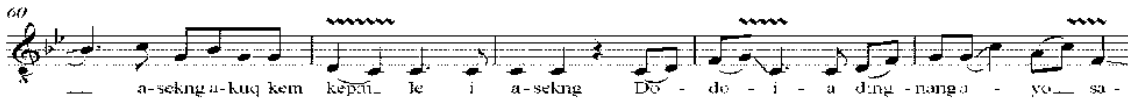

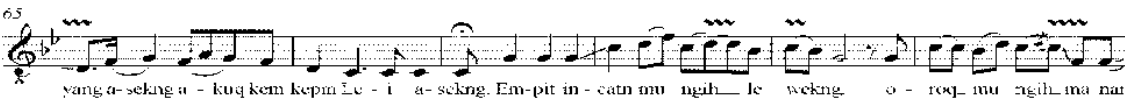

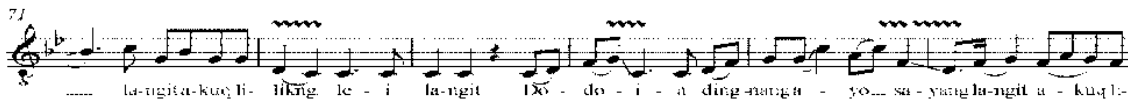

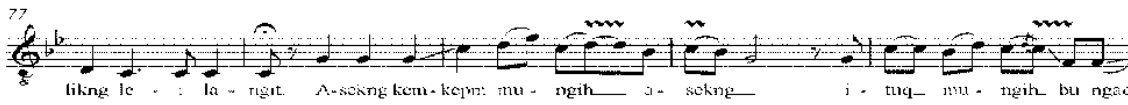

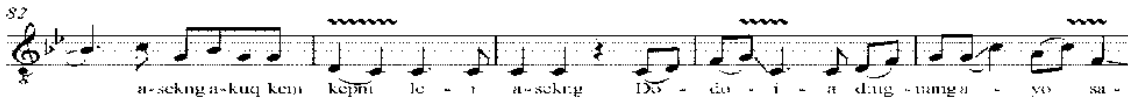

(a)

(1)

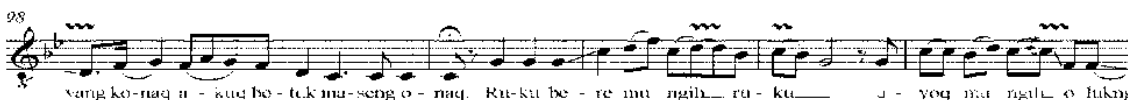
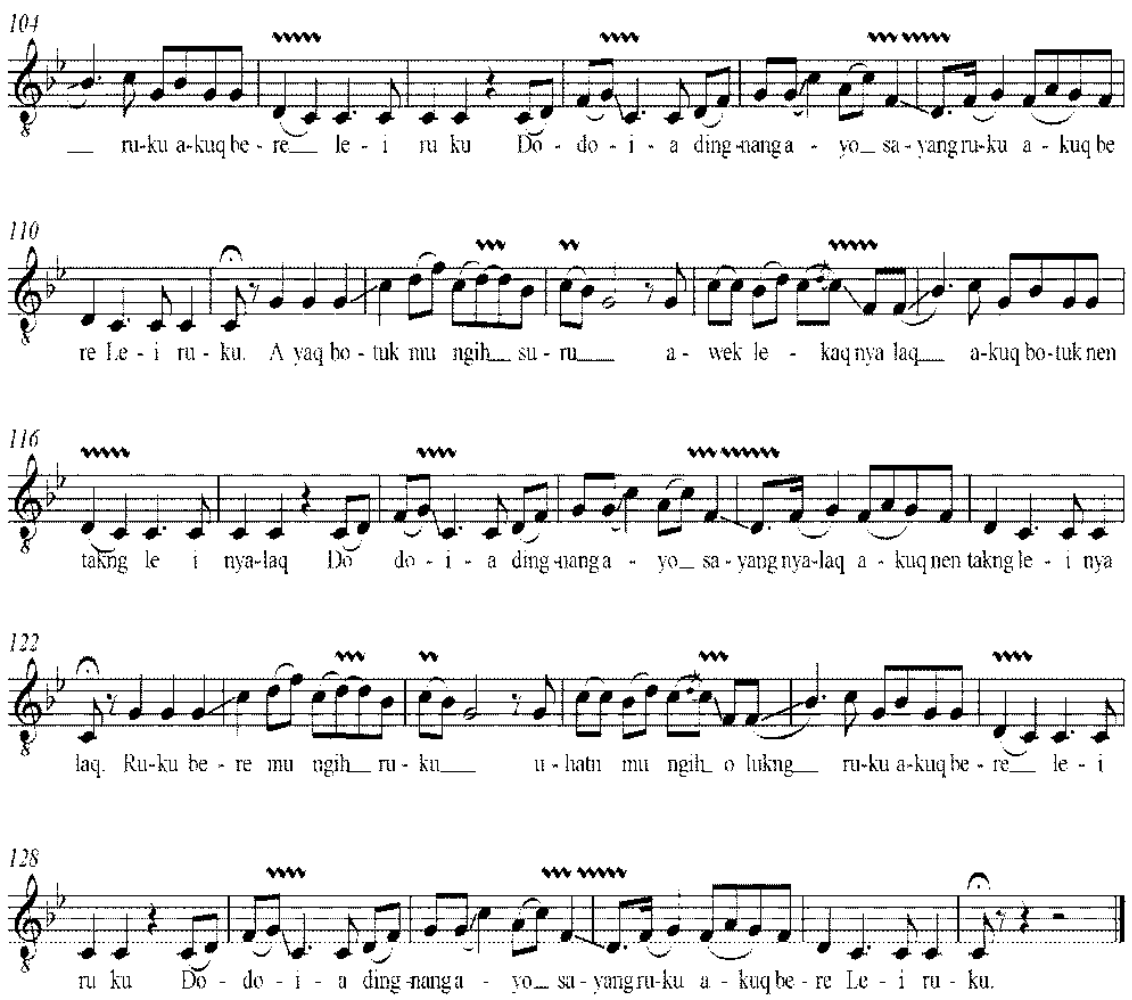